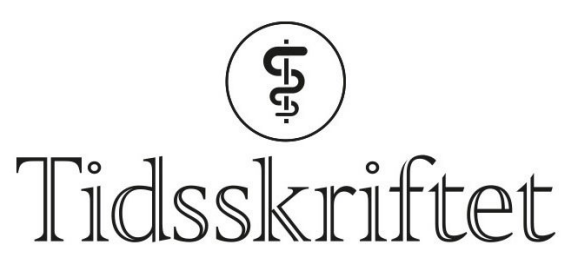

DEN NORSKE LEGEFORENING

\title{
Innsikt til utsikt!
}

KOMMENTAR

\section{BODIL OVESEN}

E-post: bodil@spiterstulen.no

Bodil Ovesen er turistvertinne.

Ingen oppgitte interessekonflikter.

I artikkelen «Lykkelig ensom» reflekterte F. E. Juul over erfaringene som turnuslege i Distrikts-Norge. Her blir han ønsket hjertelig velkommen tilbake.

Som bebuar i nevnte utkantstrøk, med jevnlig påfyll av turnuslegar, må eg få takke for godt skreve artikkel! Det skal nemnast at det er ikkje lett å vera korkje pasient eller turnuslege av og til, men jammen er oss alle heldige som har ei slik ordning. Dette er kanskje ein av dei beste rekruteringane vi har for å få nye sambygdinger. Om oss berre tek vare på dei medan dei er her. Manusforfatter viser ei god medmenneseleg forståing, og eg ynskjer han all mugleg lukke til som doktor! Velkomen attende!

Publisert: 5. mars 2018. Tidsskr Nor Legeforen. DOI: 10.4045/tidsskr.18.0149

(C) Tidsskrift for Den norske legeforening 2020. Lastet ned fra tidsskriftet.no 